\title{
The history of vegetation and climate changes of Yunnan in response to the uplift of Tibetan Plateau during the Neogene*
}

\author{
Qian-Qian Zhang ${ }^{1,3, \dagger}$, Zhao-Gang Shao ${ }^{1}$, Jian-En Han ${ }^{1}$, \\ Yue Zhao ${ }^{1}$ and Ye-Na Tang ${ }^{2}$ \\ ${ }^{1}$ Institute of Geomechanics, Chinese Academy of Geological Sciences, \\ Beijing, 100081, P. R. China \\ ${ }^{2}$ School of History \& Culture, Sichuan University, \\ Chengdu, 610065, P. R. China \\ ${ }^{3}$ Institute of Geomechanics, Chinese Academy of Geological Sciences \\ Beijing, 100081, P. R. China \\ tE-mail:xixizhangqian1984@163.com
}

\begin{abstract}
As we all know, during the Neogene the uplift of the Tibetan Plateau caused profound changes in the regional landforms and climate, and influenced the development of the Asian monsoons. The Neogene global cooling is a crucial event of geology history when the aridity in the Asian interior enhanced and the Asian monsoons intensified. In order to understand the Neogene vegetation succession and climate changes of Yunnan, previous investigations have explored the vegetation and climate based on palaeobotanical data Based on the plant fossil assemblages' fluctuations from 11 localities, we attempt to quantitatively reconstruct the palaeoenvironmental evolutions of Yunnan, and to explore the terrestrial environmental changes in response to development of the Asian monsoons. By using the palaeobotanical evidence, this research will provide a new attempt at exploring the palaeoclimate changes of Yunnan, revealing regional differences of Neogene climatic changes between Central Europe and Yunnan, and detecting the signals of the Asian monsoons on the southeastern edge of Tibetan Plateau during the Neogene.

Keywords: Palaeovegetation; Climatic changes; Asian monsoon; Tibetan Plateau; Neogene; Yunnan.
\end{abstract}

\section{Introduction}

Neogene (23.03-2.59 Ma) is a crucial phase of global climate changes. In Asian, regional climate and environment changed profoundly by the uplift of Tibetan Plateau $[1,2,3,4,5,6]$. The uplift of Tibetan Plateau gradually influenced the basic pattern of the atmospheric circulation in the northern hemisphere, triggered the onset of the Asian monsoon system, and become an important

\footnotetext{
* The authors thank Senior Engineer Nai-Qiu Du, IBCAS, Beijing, for her help with pollen identifications.This research was supported by the program of the Basic Research Program of CAGS Nos. YYWF201511 and DZLXJK201405.
} 
climate factor affecting the environmental change and biological evolution in Asia [7]. During the Neogene, Asian monsoons experienced significant and complicated evolution, among which the late Miocene is one of the key points of the evolution $[3,8,9]$. The strengthening of monsoons caused climate changed significantly in Asia and aridity in the Asian interior enhanced [4]. During the Late Miocene, the vegetation in Pakistan appeared C3 plants decreasing and C4 plants increasing $[10,11,12]$ while on the northeastern edge of Tibetan Plateau the vegetation changed from forest to steppe [13].

A large number of investigations focus on the regional differences of Neogene climatic changes among North America [e.g. 14, 15, 16], Northern Australia [e.g. 17, 18] and Europe [e.g. 19, 20, 21, 22] were carried out. The quantitative researches on the Neogene climate in China have been accumulating since the 2000s [6, 23, 24, 25, 26, 27, 28, 29, 30, 31].

Yunnan is located on southeastern edge of Tibetan Plateau (Figure 1), and its climate is influenced by the Asian monsoons and characterize by wet and dry season. The unique geographical position, special climate condition and abundant botanical resources make Yunnan one of the most important regions for studying the climate and vegetation changes caused by uplift of the Tibetan Plateau [32, 33, 34, 35]. In recent years, a series of similar quantitative researches on the Neogene climate in Yunnan have been accumulating since the 2000s [5, 30, 33, 34, 35, 36, 37].

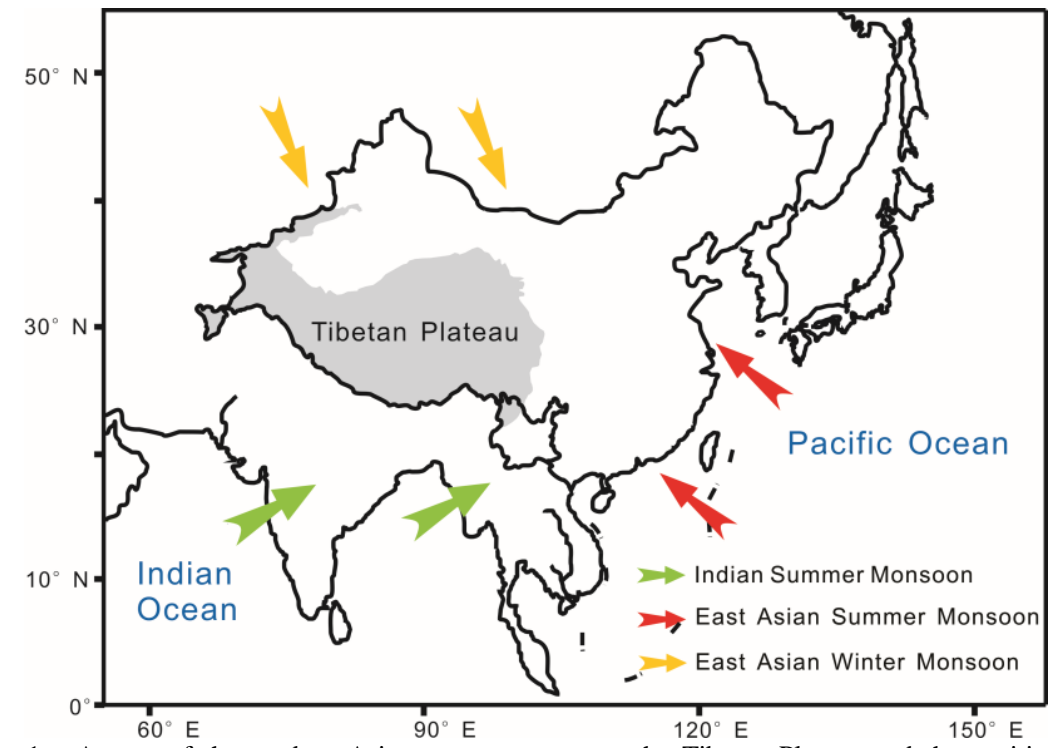

Fig. 1. A map of the modern Asian monsoon system, the Tibetan Plateau and the position of Yunnan (Modified from [4]). 
Xu [36] described the Late Pliocene palynofloras of Eryuan, Yangyi and Longling, western Yunnan and respectively quantitative reconstructed the climates of three localities. Zhao et al. [37] reported plant megafossils from the Early-Middle Miocene Nanlin Formation of the Mangdan coal-mine, including 11 taxa of angiosperms, Corylopsis, Ficus, Hypericum, Lauraceae, Lithocarpus, Magnolia, Myrica, Nyssa, Sabia, Symplocos and Zanthoxylum, suggesting an evergreen broad-leaved forest growing in Mangdan region. Kou et al. [5] recorded the pollen assemblages from Eryuan during the Late Pliocene of western Yunnan, and compared those with two contemporary palynofloras from Yangyi and Longling. They suggested the palaeotemperature was higher than present among three localities while the a doubling of the palaeoprecipitation in the Longling area between the Late Pliocene and the present. Later, Xu et al. [33] described the Late Miocene palynoflora from Lühe coal-mine, reflecting a subtropical climate conditation. Xia et al. [34] quantitative analysed the Xiaolongtan flora which supported a southern, humid subtropical climate, being more humid and having a slightly higher mean annual temperature than today. Zhang et al. [35] summarized the history of vegetation succession in four sites in southern part of Yunnan during the Middle Miocene, suggesting that the vegetation there was composed of mixed evergreen and deciduous broad-leaved forests growing under subtropical conditions. Li et al. [30] reported the Late Miocene palynoflora in Wenshan basin resembles that of modern evergreen broad-leaved forests in subtropical East Asia.

In this study, baesd on assemblages of pollen/fruits/seeds which were employed from prior researches and their NLRs in China we reconstruct the climate trends in Yunnan during the Neocene by applying the CA and we focus on seasonal ranges of temperature and precipitation in particular. The aims of our study were: (1) to design the palaeotemperature and palaeoprecipitation curves of Yunnnan based on prior botanical data and bioclimatic analyses; (2) to reveal regional differences of Neogene climatic changes between Central Europe and Yunnan; (2) to detect the signals of the Asian monsoon on the southeastern edge of Tibetan Plateau in Neogene.

\section{Materials and Methods}

Pollen/fruits/seeds taxa making up different assemblages at 11 widely distributed Yunnan fossil plant sites (Figure 2, Table 1) were used for the reconstructing changes in temperature and precipitation during Neogene. This study summarized almost all the known quantitative researches on the Neogene climate in Yunnan. 


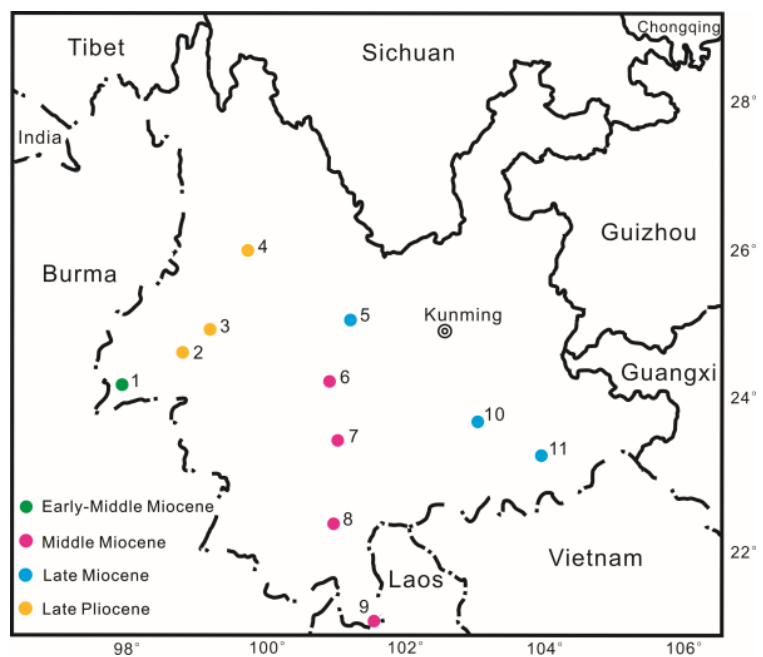

Fig. 2. Map showing the position of the 11 localities of Yunnan where prior quantitative researches have been investigated. (1. Mangdan, 2. Longling, 3. Yangyi, 4. Eryuan, 5. LüHe, 6. Jingdong, 7. Zhenyuan, 8. Puwen, 9. Mengla, 10. Kaiyuan, 11. Wenshan.)

Table 1. List of fossil localities in Yunnan (Site numbers as in Figure 1).

\begin{tabular}{|c|c|c|c|c|c|c|}
\hline Period & Site & Location & Formation & Site coordinate & Type of flora & References \\
\hline $\begin{array}{c}\text { Early-Middle } \\
\text { Miocene }\end{array}$ & 1 & Mangdan & Nanlin & $21.4^{\circ} \mathrm{N}, 97.8^{\circ} \mathrm{E}$ & Fruits/Seeds & Zhao et al. 2004 \\
\hline \multirow{4}{*}{$\begin{array}{l}\text { Middle } \\
\text { Miocene }\end{array}$} & 6 & Jingdong & Dajie & $24.3^{\circ} \mathrm{N}, 101.0^{\circ} \mathrm{E}$ & Pollen & Zhang et al. 2012 \\
\hline & 7 & Zhenyuan & Dajie & $23.6^{\circ} \mathrm{N}, 101.2^{\circ} \mathrm{E}$ & Pollen & Zhang et al. 2012 \\
\hline & 8 & Puwen & Dajie & $22.5^{\circ} \mathrm{N}, 101.0^{\circ} \mathrm{E}$ & Pollen & Zhang et al. 2012 \\
\hline & 9 & Mengla & Dajie & $21.3^{\circ} \mathrm{N}, 101.7^{\circ} \mathrm{E}$ & Pollen & Zhang et al. 2012 \\
\hline \multirow{3}{*}{$\begin{array}{c}\text { Late } \\
\text { Miocene }\end{array}$} & 5 & LüHe & Shihuiba & $25.0^{\circ} \mathrm{N}, 101.5^{\circ} \mathrm{E}$ & Pollen & Xu et al., 2008 \\
\hline & 10 & Kaiyuan & Xiaolongtan & $23.5^{\circ} \mathrm{N}, 103.2^{\circ} \mathrm{E}$ & Pollen & Xia et al., 2009 \\
\hline & 11 & Wenshan & Xiaolongtan & $23.4^{\circ} \mathrm{N}, 104.2^{\circ} \mathrm{E}$ & Pollen & Li et al., 2015 \\
\hline \multirow{3}{*}{$\begin{array}{c}\text { Late } \\
\text { Pliocene }\end{array}$} & 2 & Longling & Mangbang & $24.7^{\circ} \mathrm{N}, 98.8^{\circ} \mathrm{E}$ & Pollen & $\mathrm{Xu}, 2002$ \\
\hline & 3 & Yangyi & Yangyi & $25.0^{\circ} \mathrm{N}, 99.3^{\circ} \mathrm{E}$ & Pollen & $\mathrm{Xu}, 2002$ \\
\hline & 4 & Eryuan & Sanying & $26.0^{\circ} \mathrm{N}, 99.8^{\circ} \mathrm{E}$ & Pollen & Kou et al., 2006 \\
\hline
\end{tabular}

As a mountainous plateau which is strongly influenced by the uplift of Tibetan Plateau, Yunnan possesses complicated topography, multivariate climates and diverse plants. Geographically, it represents only $4 \%$ of China, but it contains $45.9 \%$ species of vascular plant [38]. The Asian Winter Monsoon blocked by the growing Tibetan Plateau, which caused the winter here graduaelly warmer and warmer scince Middle Miocene [35].

It has a complex terrain with a climate pattern influenced by monsoon systems. Mainly two types of modern vegetation exist in Yunnan. One type widely distributes in north and middle part of Yunnan where exists subtropical 
evergreen broad-leaved forest dominated by Castanopsis, evergreen Quercus, Lauraceae Theaceae and so on, indicative of humid and dry seasons. The other type only distributes in the southern edge of Yunnan where grows tropical rainforest and seasonal rainforest dominated by species of families such as Moraceae, Meliaceae, Sapindaceae, Palmae and so on, suggesting tropical climate [7, 29].

For the quantitative analyses of Neogene climate changes of Yunnan, 11 assemblages including 1 fruits/seeds and 10 pollen floras from 11 fossil localities have been summarized from the references. The 11 localities are listed in Table 1 together with information on their stratigraphy and sedimentology, with references concerning the type of floras.

Coexistence Approach (CA) [39] is used for quantitative bioclimatic analysis of the 11 assemblages. Based on the assumption that the climatic requirements of a fossil taxon are similar to those of its Nearest Living Relative (NLR). Analyzing the geographic distributions of all NLRs [40], the climatic parameters and coexistence intervals of the fossil taxa in a palynoflora are obtained. The modern climatic parameters of NLRs used in CA are extracted from the surface meteorological data of China[42]. Seven parameters of temperature and precipitation have been determined. These are: MAT $=$ the mean annual temperature, MWMT $=$ the mean temperature of the warmest month, MCMT=the mean temperature of the coldestmonth, DT=the difference in temperature between the coldest andwarmest months, $\mathrm{MAP}=$ the mean annual precipitation, $\mathrm{MMaP}=$ the mean maximum monthly precipitation, and $\mathrm{MMiP}=$ the mean minimum monthly precipitation.

\section{Results}

Seven parameters of temperature and precipitation were estimated based on ollen/fruits/seeds data at all 11 sites during the Neogene (Table 2). The pattern and ranges of temperature and precipitation are presented as below (Figure 3). 
Table 2. Comparison of climatic parameters of 11 fossil localities in Yunnan extended from the Early-Middle Miocene to the Late Pliocene.

\begin{tabular}{|c|c|c|c|c|c|c|c|c|c|}
\hline Period & Site & Location & MAT & MWMT & MCMT & DT & MAP & MMaP & MMiP \\
\hline $\begin{array}{l}\text { Early-Middle } \\
\text { Miocene } \\
\end{array}$ & 1 & Mangdan & $18.8-20.5$ & $27.6-28.0$ & $7.9-11.3$ & $15.2-17.9$ & $1170.0-1300.0$ & & \\
\hline \multirow{4}{*}{$\begin{array}{l}\text { Middle } \\
\text { Miocene }\end{array}$} & 6 & Jingdong & $11.5-17.3$ & $19.8-28.0$ & $-0.2-5.9$ & $12.3-24.6$ & 793.9-1389.4 & $172.4-245.2$ & $6.9-22.1$ \\
\hline & 7 & Zhenyuan & $11.5-20.8$ & $18.7-28.0$ & $-0.2-5.9$ & $12.1-26.0$ & 793.9-1389.4 & 172.4-245.2 & $5.7-22.1$ \\
\hline & 8 & Puwen & $-11.5-21.9$ & $18.7-28.0$ & $-0.2-5.9$ & $12.1-24.6$ & 793.9-1389.4 & 139.0-245.2 & 4.9-23.6 \\
\hline & 9 & Mengla & $11.5-21.9$ & $18.7-28.5$ & $-0.2-5.9$ & $12.1-26.0$ & 793.9-1389.4 & $137.3-245.2$ & $4.5-22.1$ \\
\hline \multirow{3}{*}{ Late Miocene } & 5 & $\mathrm{LüHe}$ & 13.3-20.9 & $22.5-27.5$ & $2.5-12.6$ & $12.1-24.8$ & 803.6-1254.7 & 179.4-249.6 & $10.2-18.5$ \\
\hline & 10 & Kaiyuan & $16.7-19.2$ & $25.4-26.0$ & $7.7-8.7$ & & $1215.0-1639.0$ & $224.0-248.0$ & $19.0-24.0$ \\
\hline & 11 & Wenshan & $16.6-17.5$ & $27.5-29.7$ & $2.4-5.5$ & & $1432.3-1598.9$ & $228.7-266.0$ & $21.7-48.1$ \\
\hline \multirow{3}{*}{ Late Pliocene } & 2 & Longling & $18.6-22.1$ & $22.8-27.5$ & $9.7-15.1$ & $12.3-18.1$ & $815.8-1254.7$ & 172.4-249.6 & $9.8-11.3$ \\
\hline & 3 & Yangyi & 13.3-20.9 & $22.5-27.5$ & $1.9-12.6$ & $12.3-25.5$ & $797.5-1254.7$ & $172.4-249.6$ & $7.2-12.7$ \\
\hline & 4 & Eryuan & $13.3-18.6$ & $24.6-27.5$ & $1.9-12.1$ & $14.2-16.6$ & $619.9-1484.3$ & $143.8-245.6$ & $12.7-16.4$ \\
\hline
\end{tabular}

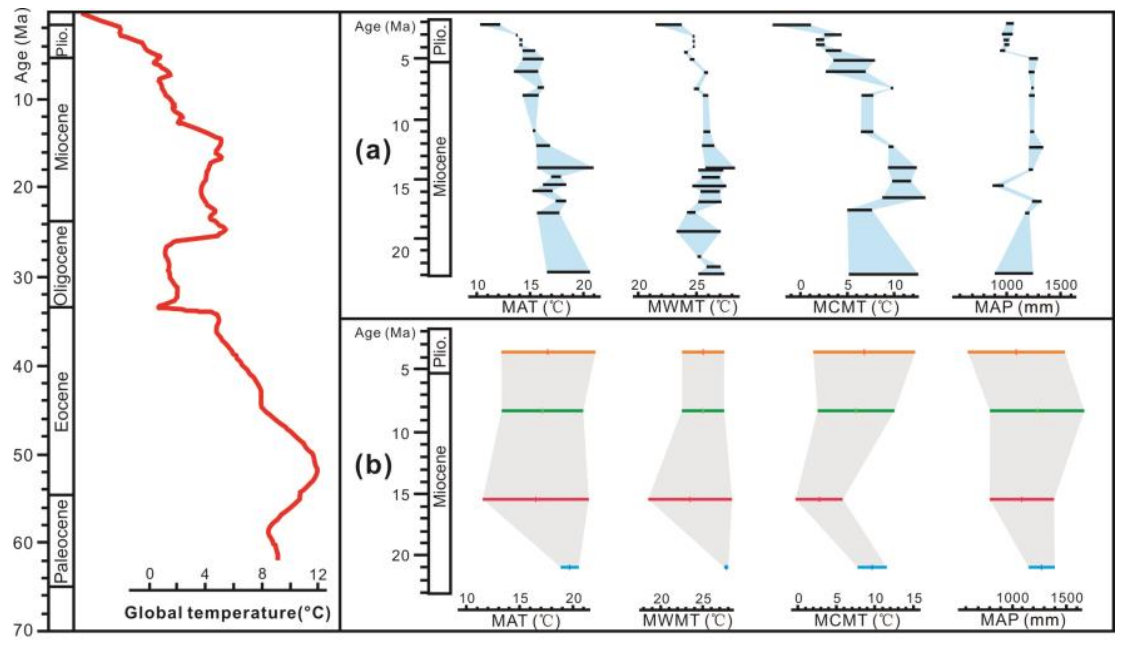

Late Pliocene climate parameters:

Late Miocene climate parameters:

Middle Miocene climate parameters:

Early-Middle Miocene climate parameters:

Fig. 3 The Neogene climatic comparison between Yunnan and Central Europe. The global temperature curve is modified from Zachos et al. (2001). a. The temperature and precipitation curves for Central Europe (modified from Mosbrugger et al., 2005). b. The temperature and precipitation curves for Yunnan.

\subsection{MAT}

Firstly, the curve showed a cooling trend from the Early-Middle to Middle Miocene with median values of MAT decreasing by $3.0{ }^{\circ} \mathrm{C}$ (from 19.7 to $16.7^{\circ} \mathrm{C}$ ) (Table 3). Secondly, a warming priod from the Middle to Late Miocene 
is characterized by MAT increasing by $0.4{ }^{\circ} \mathrm{C}$ (from 16.7 to $17.1{ }^{\circ} \mathrm{C}$ ). Finally, the warming trend continued from the Late Miocene to Late Pliocene, MAT sequentially increased by $0.6^{\circ} \mathrm{C}$ (from 17.1 to $17.7^{\circ} \mathrm{C}$ ). Generally speaking, the MAT curve showed a series of warming and cooling fluctuations. Taken as a whole, MAT curve indicated that the warmest priod of Yunnan during Neogene occurred in Early-Middle Miocene, and the MAT dropped by $2.0^{\circ} \mathrm{C}$ (from 19.7 to $17.7^{\circ} \mathrm{C}$ ).

Table 3. The Neogene temperature and precipitation evolution of Yunnan.

\begin{tabular}{|c|c|c|c|c|}
\hline Period & $\begin{array}{l}\text { MAT } \\
\text { min-max (mid) }\end{array}$ & $\begin{array}{l}\text { MWMT } \\
\text { min-max (mid) }\end{array}$ & $\begin{array}{l}\text { MCMT } \\
\text { min-max (mid) } \\
\end{array}$ & $\begin{array}{l}\text { DT } \\
\text { min-max (mid) }\end{array}$ \\
\hline Early-Mid Miocene & $18.8-20.5(19.7)$ & $27.6-28.0(27.8)$ & $7.9-11.3(9.6)$ & $15.2-17.9(16.6)$ \\
\hline Middle Miocene & $11.5-21.9(16.7)$ & $18.7-28.5(23.6)$ & $-0.2-5.9(2.9)$ & $12.1-26.0(19.1)$ \\
\hline Late Miocene & $13.3-20.9(17.1)$ & $22.5-29.7(26.1)$ & $2.4-12.6(7.5)$ & $12.1-24.8(18.5)$ \\
\hline Late Pliocene & $13.3-22.1(17.7)$ & $22.8-27.5(25.2)()()(25.15)$ & 1.9-15.1 (8.5) & $12.3-25.5(18.9)$ \\
\hline Period & $\begin{array}{l}\text { MAP } \\
\text { min-max (mid) }\end{array}$ & $\begin{array}{l}\text { MMaP } \\
\text { min-max (mid) }\end{array}$ & $\begin{array}{l}\text { MMiP } \\
\text { min-max (mid) }\end{array}$ & \\
\hline Early-Mid Miocene & $1170.0-1300.0(1235.0)$ & & & \\
\hline Middle Miocene & 793.9-1389.4 (1091.7) & $137.3-245.2(191.3)$ & $4.5-23.6(14.1)$ & \\
\hline Late Miocene & 803.6-1639.0 (1221.3) & $179.4-266.0(222.7)$ & $10.2-48.1(14.6)$ & \\
\hline Late Pliocene & $619.9-1484.3(1052.1)$ & $143.8-249.6(196.7)$ & 7.2-16.4 (11.8) & \\
\hline
\end{tabular}

\subsection{MWMT}

Firstly, from the Early-Middle to Middle Miocene, the median values of MWMT decreasing by $4.2{ }^{\circ} \mathrm{C}$ (from 27.8 to $23.6{ }^{\circ} \mathrm{C}$ ). Secondly, it increased by $2.5{ }^{\circ} \mathrm{C}$ from the Middle to Late Miocene (from 23.6 to $26.1{ }^{\circ} \mathrm{C}$ ). Finally, it dropped by $0.9{ }^{\circ} \mathrm{C}$ from the Late Miocene to Late Pliocene (from 26.1 to $25.2{ }^{\circ} \mathrm{C}$ ). Taken as a whole, MWMT curve suggested a general cooling trend during the whole Neogene dropping by $2.6{ }^{\circ} \mathrm{C}$ (from 27.8 to $25.2{ }^{\circ} \mathrm{C}$ ) (Table 3).

\subsection{MCMT}

Firstly, the curve showed a cooling trend from the Early-Middle to Middle Miocene with median values of MCMT decreasing by $6.7{ }^{\circ} \mathrm{C}$ (from 9.6 to $2.9{ }^{\circ} \mathrm{C}$ ). Secondly, a warming priod from the Middle to Late Miocene is characterized by MCMT increasing by $4.6{ }^{\circ} \mathrm{C}$ (from 2.9 to $7.5^{\circ} \mathrm{C}$ ). Finally, the warming trend of MCMT continued from the Late Miocene to Late Pliocene, with median values sequentially increasing by $1.0^{\circ} \mathrm{C}$ (from 7.5 to $8.5{ }^{\circ} \mathrm{C}$ ). Generally speaking, the MCMT curve showed a series of warming and cooling fluctuations. Taken as a whole, MCMT curve indicated that the warmest priod during Neogene occurred in the Early-Middle Miocene, and the MCMT dropped by $1.1{ }^{\circ} \mathrm{C}$ from the Early-Middle Miocene to Late Pliocene (from 9.6 to $8.5{ }^{\circ} \mathrm{C}$ ) (Table 3). 


\section{4. $D T$}

Firstly, from the Early-Middle to Middle Miocene, the median values of DT increasing by $2.5{ }^{\circ} \mathrm{C}$ (from 16.6 to $19.1{ }^{\circ} \mathrm{C}$ ). Secondly, it decreased by $0.6{ }^{\circ} \mathrm{C}$ from the Middle to Late Miocene (from 19.1 to $18.5^{\circ} \mathrm{C}$ ). Finally, it increased by $0.4{ }^{\circ} \mathrm{C}$ from the Late Miocene to Late Pliocene (from 18.5 to $18.9{ }^{\circ} \mathrm{C}$ ). Generally speaking, the DT curve showed a series of warming and cooling fluctuations. Taken as a whole, DT curve indicated that the warmest priod during Neogene occurred in Middle Miocene, and the DT increased by $2.3{ }^{\circ} \mathrm{C}$ from the Early-Middle Miocene to Late Pliocene (from 16.6 to $18.9^{\circ} \mathrm{C}$ ) (Table $3)$.

\subsection{MAP}

Firstly, the curve of MAP showed a drying trend from the Early-Middle to Middle Miocene with median values decreasing by $143.3 \mathrm{~mm}$ (from 1235.0 to $1091.7 \mathrm{~mm}$ ). Secondly, a wetting priod from the Middle to Late Miocene is characterized by MAP increasing by $129.6 \mathrm{~mm}$ (from 1091.7 to $1221.3 \mathrm{~mm}$ ). Finally, it decreased by $169.2 \mathrm{~mm}$ from the Late Miocene to Late Pliocene (from 1221.3 to $1052.1 \mathrm{~mm}$ ). Generally speaking, the MAP curve showed a series of drying and wetting fluctuations. Taken as a whole, the MAP curve indicated that the wettest priod during Neogene occurred in Early-Middle Miocene, and the MAP dropped by $182.9 \mathrm{~mm}$ from the Early-Middle Miocene to Late Pliocene (from 1235.0 to $1052.1 \mathrm{~mm}$ ) (Table 3).

\section{6. $M M a P$}

Firstly, the curve of MMaP showed a wetting trend from the Middle to Late Miocene with median values increasing by $31.4 \mathrm{~mm}$ (from 191.3 to $222.7 \mathrm{~mm}$ ). Secondly, a drying priod from the Late Miocene to Late Pliocene is characterized by $\mathrm{MMaP}$ decreasing by $26.0 \mathrm{~mm}$ (from 222.7 to $196.7 \mathrm{~mm}$ ). Taken as a whole, the MMaP curve indicated that the wettest priod during Neogene occurred in Late Miocene, and the MMaP increased by $5.4 \mathrm{~mm}$ from the Early-Middle Miocene to Late Pliocene (from 191.3 to $196.7 \mathrm{~mm}$ ) (Table 3).

\section{7. $M$ MiP}

Firstly, the curve of MMiP showed a wetting trend from the Middle to Late Miocene with median values increasing by $0.5 \mathrm{~mm}$ (from 14.1 to $14.6 \mathrm{~mm}$ ). Secondly, a drying priod from the Late Miocene to Late Pliocene is characterized by MMiP decreasing by $26.0 \mathrm{~mm}$ (from 14.6 to $11.8 \mathrm{~mm}$ ). Taken as a whole, the MMiP curve indicated that the wettest priod during Neogene 
occurred in Late Miocene, and the MMiP decreased by $2.3 \mathrm{~mm}$ from the Early-Middle Miocene to Late Pliocene (from 14.1 to $11.8 \mathrm{~mm}$ ) (Table 3).

\section{Discussion}

\subsection{The climate changes in Yunnan during Neogene comparison with those in Central Europe}

The Neogene temperature and precipitation curves of Yunnan were compared with those from the global marine temperature record and from Central Europe $[19,42]$ (Figure 3). It revealed that:

MAT: in contrast to the Neogene cooling [19, 42], MAT curves of Yunnan exhibited cooling first and then warming. Generally speaking, the decrease in MAT in Yunnan was gentler than in Central Europe since the Early-Middle Miocene. MAT dropped by $2.0^{\circ} \mathrm{C}$ in Yunnan (from 19.7 to $17.7^{\circ} \mathrm{C}$ ) and by approximately $7.4^{\circ} \mathrm{C}$ in Central Europe (from 18.5 to $11.1{ }^{\circ} \mathrm{C}$ ). The temperature was $6.6{ }^{\circ} \mathrm{C}$ higher in Yunnan than in Central Europe during the Late Pliocene $\left(17.7\right.$ vs. $11.1^{\circ} \mathrm{C}$ ), while it was $1.2^{\circ} \mathrm{C}$ higher in Yunnan than in Central Europe during the Early-Middle Miocene $\left(19.7\right.$ vs. $18.5^{\circ} \mathrm{C}$ ) (Figure 3).

MWMT: The decrease in MWMT in Yunnan and that in Central Europe were more or less similar. MWMT dropped by $2.6^{\circ} \mathrm{C}$ (from 27.8 to $25.2^{\circ} \mathrm{C}$ ) in Yunnan and by $3.4{ }^{\circ} \mathrm{C}$ (from 26.1 to $22.7{ }^{\circ} \mathrm{C}$ ) in Central Europe since the Early-Middle Miocene (Figure 3).

MCMT: The decrease in MCMT in Yunnan was much gentler than in Central Europe. MCMT only dropped by $1.1^{\circ} \mathrm{C}$ from the Early-Middle Miocene to Late Pliocene (from 9.6 to $8.5^{\circ} \mathrm{C}$ ) in Yunnan, while it dropped by $9.8{ }^{\circ} \mathrm{C}$ (from 8.9 to $-0.9{ }^{\circ} \mathrm{C}$ ) in Central Europe during the Neogene. The MCMT in Yunnan and that in Central Europe were more or less similar during the Early-Middle Miocene ( 9.6 vs. $8.9^{\circ} \mathrm{C}$ ), but difference of winter temperatures between East China and Central Europe was $9.4{ }^{\circ} \mathrm{C}\left(8.5\right.$ vs. $\left.-0.9{ }^{\circ} \mathrm{C}\right)$ during the Late Pliocene (Figure 3).

MAP: In Central Europe, the MAP curve showed a series of wetting and drying fluctuations (Mosbrugger et al., 2005). Taken as a whole, MAP curve of Yunnan indicated that regional drying happened in Early-Middle Miocene with MAP dropped by $182.9 \mathrm{~mm}$ from the Early-Middle Miocene to Late Pliocene (from 1235.0 to $1052.1 \mathrm{~mm}$ ). Generally speaking, the decrease in MAP in Central Europe was gentler than in Central Europe since the Early-Middle Miocene. (Figure 3). 


\subsection{The signals of the Asian monsoon on the southeastern edge of Tibetan Plateau in Neogene}

All three temperature curves (MAT, MWMT, MCMT) exhibit cooling trends from Early-Middle to Middle Miocene, then warming from Middle Miocene to Late Pliocene. The decrease of temperature in Middle Miocene might signal the strengthening of the Asian Winter Monsoon [4]. Since Middle Miocene temperature curves all showed increasing trends which most likely caused by the uplift of the Tibetan Plateau, which has succeeded in blocking the Asian Winter Monsoon since the Middle Miocene.

The precipitation curve (MAP) exhibited drying trend from Early-Middle to Middle Miocene, and this phenomenon might be influenced by the enhanced aridity in the Asian interior [4].

\section{Conclusion}

The compared palaeoclimatic studies in Yunnan, at the southeastern edge of the Tibetan Plateau, lead to the following conclusions:

1. In contrast to the global cooling, Yunnan palaeoclimate exhibited cooling first and then warming during the Neogene. The decrease in MAT in Yunnan was gentler than in Central Europe since the Early-Middle Miocene.

2. The winter temperature changes were more obvious than the summer temperature changes in Yunnan since the Miocene.

3. The decrease of palaeotemperature might signal the strengthening of the Asian Winter Monsoon in Middle Miocene. In our study the climate exhibited warming trends which most likely caused by the uplift of the Tibetan Plateau, which has succeeded in blocking the Asian Winter Monsoon since the Middle Miocene.

\section{References}

1. Harrison T.M., Copeland P., Kidd W.S.F., Yin A. 1992. Raising Tibet. Science 255, 1663-1670.

2. Kutzbach F.E., Prell W.L., Ruddiman W.F. 1993. Sensitivity of Eurasian climate to surface uplift of the Tibetan Plateau. Journal of Geology 101, 177-190.

3. Molnar P., England P., Martinod J. 1993. Mantle dynamics, uplift of the Tibetan plateau, and the Indian monsoon. Reviews of Geophysics 31, 357-396.

4. An, Z.S., Kutzbach, J.E., Prell, W.L., Porter, S.C. 2001. Evolution of Asian monsoons and phased uplift of the Himalaya-Tibetan plateau since Late Miocene times. Nature 411, 62-66. 
5. Kou X.Y., Ferguson D.K., Xu J.X., Wang Y.F., Li C.S. 2006. The reconstruction of paleovegetation and paleoclimate in the Late Pliocene of west Yunnan, China. Climate Change 77, 431-448.

6. Qin F., Ferguson D.K., Zetter R., Wang Y.F., Syabryaj S., Li J.F., Yang J., Li C.S. 2011. Late Pliocene vegetation and climate of Zhangcun region, Shanxi, North China. Global Change Biology 17, 1850-1870.

7. Sun X.J., Wang P.X. 2005. Howold is the Asian monsoon system? Palaeobotanical record from China. Palaeogeography, Palaeoclimatology, Palaeoecology 222, 181-222.

8. Prell W.L., Kutzbach J.E. 1992. Sensitivity of the Indian monsoon to forcing parameters and implications for its evolution. Nature 360, 647-652.

9. Zheng H.B., Powell C.M., Rea D.K., Wang J.L., Wang P.X. 2004. Late Miocene and mid-Pliocene enhancement of the East Asian monsoon as viewed from the land and sea. Global and Planetary Change 41, 147-155.

10. Cerling T.E., Harris J.M., MacFadden B.J., Leakey M.G., Quadek J., Eisenmann V., Ehleringer J.R. 1997. Global vegetation change through the Miocene/Pliocene boundary. Nature 389, 153-158.

11. Osborne C.P. 2008. Atmosphere, ecology and evolution: what drove the Miocene expansion of C4 grasslands. Journal of Ecology 96, 35-45.

12. Edwards E.J., Osborne C.P., Strömberg C.A.E. et al. 2010. The origins of C4 grasslands: integrating evolutionary and ecosystem science. Science 328, 587-591.

13. Ma Y.Z., Li J.J., Fang X.M. 1998. The palynofloras and climate changes of Red Layer from Linxia area during 30.6-5.0 Ma. Science Bulletin 43, 301-304.

14. Wolfe J.A. 1994. Tertiary climatic changes at middle latitudes of western North America. Palaeogeography, Palaeoclimatology, Palaeoecology 108, 195-205.

15. Wolfe J.A. 1995. Paleoclimatic estimate from Tertiary leaf assemblages. Annual Review of Earth and Planetary Sciences 23, 119-142.

16. Retallack G.J. 2007. Cenozoic paleoclimate on land in North America. Journal of Geology 115, 271-294.

17. Kershaw A.P., Wagstaff B. 2001. The southern conifer family Araucariaceae: history, status, and value for paleoenvironmental reconstruction. Annual Review of Ecology and Systematics 32, 397-414.

18. Kershaw A.P., van der Kaars S., Flenley J.R. 2007. The Quaternary history of Far Easter rainforests. In: Bush, M.B., Flenley, J.R. (Eds.), Tropical Rainforest Responses to Climatic Change. Praxis Publishing Ltd, Chichester, pp. 77-115. 
19. Mosbrugger V., Utescher T., Dilcher D.L. 2005. Cenozoic continental climate evolution of Central Europe. Proceedings of the National Academy of Sciences of the United States of America 102, 14964-14969.

20. Böhme, M., Bruch, A.A., Selmeier, A. 2007. The reconstruction of Early and Middle Miocene climate and vegetation in Southern Germany as determined from the fossil wood flora. Palaeogeography, Palaeoclimatology, Palaeoecology 253, 91-114.

21. Uhl D., Klotz S., Traiser C., Thiel C., Utescher T., Kowalski E., Dilcher D.L. 2007. Cenozoic paleotemperatures and leaf physiognomy-a European perspective. Palaeogeography, Palaeoclimatology, Palaeoecology 248, 24-31.

22. Utescher T., Mosbrugger V., Ivanov D., Dilcher D.L. 2009. Present-day climate equivalents of European Cenozoic climates. Earth and Planetary Science Letters 284, 544-552.

23. Sun Q.G., Collinson M.E., Li C.S., Wang Y.F., Beerling D.J. 2002. Quantitative reconstruction of palaeoclimate from the Middle Miocene Shanwang flora, eastern China. Palaeogeography, Palaeoclimatology, Palaeoecology 180, 315-329.

24. Yang J., Wang Y.F., Sun Q.G., Li C.S. 2002. Quantitative studies on paleoelevation and paleoclimate of Shanwang Miocene basin, east China. Earth Science Frontiers 9, 183-188 (in Chinese with English abstract).

25. Yang J., Wang Y.F., Spicer R.A., Mosbrugger V., Li C.S. 2007. Climatic reconstruction at the miocene Shanwang Basin, China, using leaf margin analysis, CLAMP, coexistence approach, and overlapping distribution analysis. American Journal of Botany 94, 599-608.

26. Liang M.M., Bruch A.A., Collinson M.E., Mosbrugger V., Li C.S., Sun Q.G., Hilton J. 2003. Testing the climatic estimates from different palaeobotanical methods: an example from the Middle Miocene Shanwang flora of China. Palaeogeography, Palaeoclimatology, Palaeoecology 198, 279-301.

27. Li J.F., Ferguson D.K., Yang J., Feng G.P., Ablaev A.G., Wang Y.F., Li C.S. 2009. Early Miocene vegetation and climate in Weichang District, North China. Palaeogeography, Palaeoclimatology, Palaeoecology 280, 47-63.

28. Li J.F., Hu Y.Q., Ferguson D.K., Wang Y.F., Li C.S. 2010. An Early Pliocene lake and its surrounding vegetation in Zhejiang, East China. Journal of Paleolimnology 43, 751-769.

29. Yao Y.F., Bruch A.A., Mosbrugger V., Li C.S. 2011. Quantitative reconstruction of Miocene climate patterns and evolution in Southern China 
based on plant fossils. Palaeogeography Palaeoclimatology Palaeoecology 304, 291-307.

30. Li SF, Mao LM, Spicer RA et al. 2015. Late Miocene vegetation dynamics under monsoonal climate in southwestern China. Palaeogeography, Palaeoclimatology, Palaeoecology 425: 14-40.

31. Zhang Q.Q., Smith T., Yang J., Li C.S. 2016. Evidence of a Cooler Continental Climate in East China during the Warm Early Cenozoic. Plos One 11(5): e0155507.

32. WGCPC (Writing Group of Cenozoic Plants of China). 1978. Cenozoic Plants from China, Fossil Plants of China, vol. 3. Sci. Press, Beijing, pp. 183-185 (in Chinese).

33. Xu J.X., Ferguson D.K., Li C.S., Wang Y.F. 2008. Late Miocene vegetation and climate of the Lühe region in Yunnan, southwestern China. Review of Palaeobotany and Palynology 148, 36-59.

34. Xia K., Su T., Liu Y.S., Xing Y.W., Jacques F.M.B., Zhou Z.K. 2009. Quantitative climate reconstructions of the late Miocene Xiaolongtan megaflora from Yunnan, southwest China. Palaeogeography, Palaeoclimatology, Palaeoecology 276, 80-86.

35. Zhang Q.Q., Ferguson D.K., Mosbrugger V., Wang Y.F., Li C.S. 2012. Vegetation and climatic changes of SW China in response to the uplift of Tibetan Plateau. Palaeogeography Palaeoclimatology Palaeoecology 362-364, 23-36.

36. Xu JX. 2002, Palynology, Paleovegetation and Paleoclimate of Neogene, Central-Western Yunnan, China, Ph. D. thesis, Institute of Botany, the Chinese Academy of Sciences, Beijing, China pp. 1-158 (in Chinese with English abstract).

37. Zhao L.C., Wang Y.F., Liu C.J., Li C.S. 2004. Climatic implications of fruit and seed assemblage from Miocene of Yunnan, southwestern China. Quaternary International 117, 81-89.

38. WGYV (Writing Group of Yunnan Vegetation). 1987. Vegetation of Yunnan, Science Press, Beijing, pp. 1-843 (in Chinese).

39. Mosbrugger V., Utescher T. 1997. The coexistence approach-a method for quantitative reconstruction of Tertiary terrestrial palaeoclimate data using plant fossils. Palaeogeography, Palaeoclimatology, Palaeoecology 134, 61-86.

40. Wu Z.Y., Ding T.Y. 1999. Seed Plants of Yunnan. China. Science Technology Press, Kunming (in Chinese).

41. IDBMC (Information Department of Beijing Meteorological Center). 1984. Land climate data of China (1951-1980) (part I-VI). China Meteorology Press, Beijing (in Chinese). 
42. Zachos L., Pagani M., Sloan L., Thomas E., Billups K. 2001. Trends, rhythms, and aberrations in global climate 65 Ma to present. Science 292, 686-693. 